\title{
Nutritional Significance of Sulphur on Growth, Yield and Quality of Blackgram in Major Contrasting Soil Series of Tamil Nadu, India
}

\author{
B. Gokila ${ }^{1^{*}}$, K. Baskar ${ }^{2}$ and P. Saravanapandian ${ }^{2}$ \\ ${ }^{1}$ Long Term Fertilizer Experiment, ${ }^{2}$ Department of Soil Science and Agricultural Chemistry, \\ Tamil Nadu Agricultural University, Coimbatore - 641 003, Tamil Nadu, India \\ *Corresponding author
}

\section{A B S T R A C T}

Sulphur is an essential element for plant growth because it is present in major metabolic compounds such as amino acids (methionine and cysteine), glutathione, proteins, and sulpho lipids in oil seeds and pulses. Pulses are particularly sensitive to S deficiency, which imparts the low quality of seeds and yield. Therefore, the investigation was assessed

\section{Keywords}

Blackgram, Sulphur, Alfisols, Vertisols, Vylogam and

Peelamedu series.

Article Info

Accepted:

24 September 2017

Available Online:

10 November 2017 with three different $\mathrm{S}$ sources as Gypsum, Ammonium sulphate and Potassium sulphate were tried at two levels ( $\mathrm{S} @ 10$ and $20 \mathrm{~kg} \mathrm{ha}^{-1}$ ). Field experiment were conducted during rabi season of 2014 to study the effect of yield and quality of irrigated blackgram as influenced by the sulphur application in Peelamedu (TypicHaplustert) and Vylogam series (TypicRhodustalf). The result revealed that, the highest growth parameters such as plant height $(54.7 \mathrm{~cm}, 55.9 \mathrm{~cm})$, Number of leaves plant ${ }^{-1}(54.8,58.8)$, Number of pods plant ${ }^{-1}$ $(34.7,38.8)$, Number of seed $\operatorname{pod}^{-1}(7.4,8.4)$ like yield parameters such as grain $(1145$, $\left.1275 \mathrm{~kg} \mathrm{ha}^{-1}\right)$ and straw yield $\left(1645,1990 \mathrm{~kg} \mathrm{ha}^{-1}\right)$ and quality parameters viz., protein (23, $24.2 \%)$ and methionine $\left(8.92,8.97 \mathrm{mg} \mathrm{g}^{-1}\right)$ were significantly increased by the different $\mathrm{S}$ sources when compared to control in Vylogam and Peelamedu series. Irrespective of the different S sources, S @ $20 \mathrm{~kg} \mathrm{ha}^{-1}$ as $\mathrm{K}_{2} \mathrm{SO}_{4}$ coupled with recommended dose of fertilisers plus $0.5 \% \mathrm{~K}_{2} \mathrm{SO}_{4}$ foliar spray at $30^{\text {th }}$ and $45^{\text {th }}$ DAS were significantly registered better response in blackgram at both the series. The synergistic effect of sulphur with NPK fertilisers on blackgram growth, yield and quality characters in alfisols and vertisols of Tamil Nadu.

\section{Introduction}

Blackgram (Vigna mungo) is one of the most important pulse crops grown in India, particularly Tamil Nadu. It is mainly grown for human consumption but also used as fodder for cattle and green manure for soil fertility. Seeds are mainly cooked, as 'Dal' in our country. Being a legume crop, blackgram has the ability to fix atmospheric nitrogen symbiotically with the nodule producing bacteria Rhizobium sp. Responses of blackgram to added fertilizers such as nitrogen and phosphorus have been found to vary with soil conditions. Increase of pulse production is urgently needed to meet up the demand of the people to reduce import, to save foreign currency and to increase pulse consumption for maintaining good health. Increase of pulse production can also minimize the scarcity of fodder because the whole plant or it is by products can he used as good animal feed. Pulses in India have long been considered as the poor man's meat and 
important diet due to rich in protein that nutritionally imbalances the protein from cereal grain, supply minerals and vitamins and provide an abundance of energy. But protein deficiency is a chronic problem in the developing countries like India. The World Health Organization recommends a per capita consumption of pulses at $80 \mathrm{~g}$ per day and the Indian council of Medical Research has a recommended a minimum consumption of 47 grams but at present the per capita availability of pulses is only $40 \mathrm{~g}$ per day in India (Chaturvediand Masood Ali, 2002). Modern intensive farming has resulted in higher demand for fertilizer because of removal of all the essential nutrients in higher proportions by the crops. Most of our attention for fertilizer use has been restricted to the use of $\mathrm{N}, \mathrm{P}$ and $\mathrm{K}$, the three primary nutrients required by the crops in large quantities. Sulphur is an important secondary nutrient elements and it is indispensable for the synthesis of certain amino acids like cysteine, cystine and methionine besides being involved in various metabolic and enzymatic processes of plants (Schnug, 1991; McGrath et al., 1996 and Zhao et al., 1999). It is a constituent of protein and glutathione, a compound that play an important role in plant respiration and synthesis of essential oils. In countries like India, vitally concerned with increasing of food production, $S$ is one element that must not be overlooked. Low $\mathrm{S}$ levels in Indian soils is regularly the main reason for low yield of cereals, pulses, oilseeds and commercial crops due to its involvement in the assimilation of nitrogen, photosynthesis, in synthesis of proteins and $\mathrm{S}$ containing amino acids. The widespread $\mathrm{S}$ deficiency in Indian soils depends more on climate, vegetation, parent material, soil texture, and management practices. Sulphur and nitrogen both are required for the synthesis of protein; therefore, the ratio of total $\mathrm{N}$ to total $\mathrm{S}$ in plant tissue can reflect the ability of $\mathrm{N}$ and $\mathrm{S}$ in protein synthesis
(Brunold and Suter, 1984). Singh and Aggarwal (1998) found that among the sources of sulphur, gypsum produced significantly higher pods per plant and seed per pod of black gram. Singh et al., 1999 reported that potassium sulphate was significantly better than elemental sulphur and pyrite but remained on par with gypsum in production of pods per plant and seeds per pod of Lentil. Sharma and Singh (1997) reported that application of sulphur at the rate of $40 \mathrm{~kg} \mathrm{ha}^{-1}$ enhanced plant height, branches, pod per plant and 1000 gram weight in green gram. Application of S @ $40 \mathrm{~kg} \mathrm{ha}^{-1}$ may be regarded as beneficial dose of sulphur application from the point of view of more protein content in seed of black gram. Information on sulphur with blackgram in vylogam and peelamedu series is rather limited. Bearing this background, the present study was undertaken to evaluate the effect of sulphur on yield and quality of blackgram in Typic Haplustert of Madurai district.

\section{Materials and Methods}

A field experiment was conducted in private fertiliser firm (BG crop sciences) at Thenamallur village , T.Kalligudi block , Madurai district with the test crop of Black gram during the year and the experimental site is located at $9^{\circ} 41^{\prime} 17.6^{\prime \prime} \mathrm{N}$ latitude and $77^{\circ} 55^{\prime} 50.6$ 'E longitude at an elevation of 127 meters above mean sea level. The soils of the experimental site belonged to Vylogam series and according to USDA soil taxonomy it is classified as Sandy clay loam, fine loamy mixed isohyperthermic Typic Rhodustalf. Initial nutrient status and characteristics of the experimental site of this series was low in $\mathrm{KMnO}_{4}-\mathrm{N}\left(234 \mathrm{~kg} \mathrm{ha}^{-1}\right)$, high in Olsen - P $\left(24.8 \mathrm{~kg} \mathrm{ha}^{-1}\right)$, medium in $\mathrm{NH}_{4} \mathrm{OAc}-\mathrm{K}(244$ $\left.\mathrm{kg} \mathrm{ha}{ }^{-1}\right)$, deficient in $\mathrm{CaCl}_{2}$ extractable $\mathrm{S}$ (9.9 $\left.\mathrm{mg} \mathrm{kg}{ }^{-1}\right)$, medium status in organic carbon $\left(5.43 \mathrm{~g} \mathrm{~kg}^{-1}\right)$, deficient in DTPA extractable $\mathrm{Zn} \quad\left(0.92 \mathrm{mg} \quad \mathrm{kg}^{-1}\right)$, sufficient DTPA 
extractable $\mathrm{Fe}\left(9.10 \mathrm{mg} \mathrm{kg}{ }^{-1}\right)$, moderate in DTPA extractable $\mathrm{Cu}\left(1.64 \mathrm{mg} \mathrm{kg}^{-1}\right)$ and high in DTPA extractable $\mathrm{Mn}\left(34.8 \mathrm{mg} \mathrm{kg}^{-1}\right)$ of sandy clay loam.

The second field experiment was conducted at farmer's field of Annaikaripatti village, $\mathrm{T}$. Kallupatti block, Madurai district with the test crop of Black gram (VBN4) during 2014. The experimental site is located at $9^{\circ} 40^{\prime} \mathrm{N}$ latitude and $77^{\circ} 35^{\prime} \mathrm{E}$ longitude at an elevation of 215 meters above mean sea level. The soils of the experimental site belonged to Peelamedu series and according to USDA soil taxonomy it has been classified as clay loam, fine montmorillonitic isohyperthermic Typic Haplustert. The characteristics of the both experimental soilare presented in Table 1. In Peelamedu series, the soils were clay loam with the neutral $\mathrm{pH}$ of 7.40 and non-saline electrical conductivity of $0.30 \mathrm{dSm}^{-1}$. The total sesquioxides and AEC were recorded as low of 4.50 per cent and $2.40 \mathrm{c} \mathrm{mol}_{\mathrm{c}} \mathrm{kg}$ ${ }^{1}$ respectively. The available $\mathrm{N}, \mathrm{P}$ and $\mathrm{K}$ status of the soils were low, high and medium of 261, 25.4 and $298 \mathrm{~kg} \mathrm{ha}^{-1}$ respectively. The available $\mathrm{CaCl}_{2}-\mathrm{S}$ was low of $9.30 \mathrm{mg} \mathrm{kg}^{-1}$.

Blackgram (Vigna mungo L.) variety VBN 4 was used as a test crop in both the field experiments to evaluate the efficacy of sulphur on growth, yield and quality of blackgram. We sow two seeds per hill and thinned after 6 days after germination. Spacing was $45 \times 15 \mathrm{~cm}$. Irrigation was scheduled at every ten days interval after the life irrigation was given. The experimental design used was randomised block design with three replications. Recommended dose of fertilizer as NPK @ 25: 50: $25 \mathrm{~kg} \mathrm{ha}^{-1}$. Three $\mathrm{S}$ fertilizer sources [Gypsum $\left(\mathrm{Ca} \mathrm{SO}_{4}\right)$, ammonium sulphate $\left(\mathrm{NH}_{4} \quad \mathrm{SO}_{4}\right)$ and potassium sulphate $\left(\mathrm{K}_{2} \mathrm{SO}_{4}\right)$ ] and two levels (S@10, $20 \mathrm{~kg} \mathrm{ha}^{-1}$ ) and soil application(as basal dose), foliar spray (only $0.5 \% \quad \mathrm{~K}_{2} \mathrm{SO}_{4}$ ) and combined application along with control a total 14 treatments were used for the experiment during 2014. All the experimental data were statistically analysed as per the procedure outlined by Gomez and Gomez (1984).

\section{Results and Discussion}

\section{Effect of sulphur application on growth parameters of blackgram}

\section{Plant height (cm)}

Sources and levels of sulphur significantly influenced the plant height at harvest stage of blackgram which varied from 45.4 to $54.7 \mathrm{~cm}$ and 44.8 to 55.9 cmin Vylogam and Peelamedu series respectively (Table 2 ). The highest plant height of $54.7 \mathrm{~cm}$ in the treatment receiving $\mathrm{S} @ 20 \mathrm{~kg} \mathrm{ha}{ }^{-1}$ as Potassium sulphate plus 0.5 per cent $\mathrm{K}_{2} \mathrm{SO}_{4}$ foliar spray plus 100 per cent $\mathrm{RDF}\left(\mathrm{T}_{9}\right)$ and this was on par with S @ $20 \mathrm{~kg} \mathrm{ha}^{-1}$ as potassium sulphate plus 100 per cent RDF $\left(\mathrm{T}_{8}\right)(54.5 \mathrm{~cm})$. Regarding Peelamedu series, the treatment $\mathrm{T}_{9}$ recorded highest plant height of $55.9 \mathrm{~cm}$ followed by $\mathrm{T}_{8}(55.3 \mathrm{~cm})$ in blackgram. This was ascribed due to the increasing levels of sulphur could have increased the ferridoxin content which is responsible for nodulation activity. Ferridoxin are rich in sulphur and contain $\mathrm{Fe}-\mathrm{S}$ clusters which play vital role in $\mathrm{N}_{2}$ fixation. These nodulation encourage the activity of rhizhosphere region increases the nutrient retention in root zone which in turn increased the nutrient absorption and translocation from assimilate to shoot encourage the plant height of blackgram. In both locations $\mathrm{S}$ application increases the plant height augmented to synergism of sulphur with $\mathrm{N}$ and other macro and micro nutrients which has increased the plant height of blackgram. This was supported by the findings of Fahmina Akter et al., (2013) who revealed that among the different fertilizer doses, application of S @ $40 \mathrm{~kg} \mathrm{ha}^{-1}$ 
recorded the highest plant height which was statistically similar with $20 \mathrm{~kg} \mathrm{~S}^{-1}$ this was ascribed to the favourable effects of sulphur on N-metabolism and consequently on the vegetative growth of soybean.

\section{Number of leaves per plant}

The significant influences of sulphur application on number of leaves per plant of blackgram was ranged from 37.1 to 54.8 and 38.2 to 58.8 in Vylogam and Peelamedu series respectively (Table 2). The higher number of leaves per plant was noticed at $S$ @ $20 \mathrm{~kg} \mathrm{ha}^{-1}$ as Potassium sulphateplus 0.5 per cent $\mathrm{K}_{2} \mathrm{SO}_{4}$ foliar spray plus 100 per cent RDF $\left(\mathrm{T}_{9}\right)$ of 54.8 and this was on par with $\mathrm{S}$ (a) $20 \mathrm{~kg} \mathrm{ha}^{-1}$ as potassium sulphateplus 100 per cent RDF $\left(\mathrm{T}_{8}\right)$ (52.8) as compared to other treatments in Vylogam series. Regarding Peelamedu series, $\mathrm{T}_{9}$ recorded the highest number of leaves per plant (58.8) followed by $\mathrm{T}_{8}(53.1)$.

There was significant influences of sulphur application on number of leaves per plant in blackgram and the highest number of leaves per plant was noticed in S @ $20 \mathrm{~kg} \mathrm{ha}^{-1}$ as Potassium sulphate plus 0.5 per cent $\mathrm{K}_{2} \mathrm{SO}_{4}$ foliar spray plus 100 per cent $\mathrm{RDF}\left(\mathrm{T}_{9}\right)$ as compared to other treatments both in Vylogam and Peelamedu series. This was ascribed due to the $\mathrm{S}$ application leads to higher absorption and translocation of nutrients assimilates to shoot which has increased the number of leaves per plant in blackgram. This result was corroborating with the findings of Mir et al., (2013) who augmented that among the sulphur levels, application of sulphur @ 40 kg ha ${ }^{-1}$ significantly increased the number of leaves per plant in blackgram as compared to no sulphur application. This significant influence of sulphur application on increasing the growth and yield might be attributed to its role in chlorophyll synthesis.
Effect of sulphur on yield and yield attributes

\section{Number of pods per plant}

Application of treatment influenced number of pods per plant and it ranged from 24.7 to 34.7and 28.9 to 38.8 in Vylogam and Peelamedu series respectively (Table 2). Among the treatments, the number of pods per plant recorded the highest in the treatment receiving $\mathrm{S} @ 20 \mathrm{~kg} \mathrm{ha}^{-1}$ as Potassium sulphate plus 0.5 per cent $\mathrm{K}_{2} \mathrm{SO}_{4}$ foliar spray plus 100 per cent RDF ( $\left.\mathrm{T}_{9}\right)$ of 34.7 followed by $\mathrm{T}_{8}\left(\mathrm{~S} @ 20 \mathrm{~kg} \mathrm{ha}^{-1}\right.$ as Potassium sulphate plus 100 per cent RDF)(33.2) in Vylogam series. In Peelamedu series, the highest number of pods per plant was noticed in $\mathrm{T}_{9}$ (38.8) followed by $\mathrm{T}_{8}$ (37.4). This was augmented that application of $\mathrm{S}$ increases the yield by increasing the $S$ from source (assimilate) to sink (seed) which would have increased the number of pods per plant. Besides, $\mathrm{S}$ application increases the photosynthetic activity over all growing environment (rhizohsphere region of roots) and greater partitioning of metabolites and adequate translocation of nutrients to developing structure leads to increase the number of pods per plant in blackgram.

This result was corroborated with the findings of Kokani et al., (2014) who found that application of S @ $20 \mathrm{~kg} \mathrm{ha}^{-1}$ had registered significantly higher number of pods per plant which had been attributed that sulphur improve overall nutritional environment of the rhizosphere as well as in the plant system, which in turn enhanced the plant metabolism and photosynthetic activity resulting in better growth and yield attributes of plant.

\section{Number of seeds per pod}

The result envisaging the number of seeds per plant of blackgram arranged from 5.1 to 7.4 
and 6.1 to 8.4 in Vylogam and Peelamedu series respectively (Table 2). The highest number of seeds per pod was registered in the treatment receiving $\mathrm{S} @ 20 \mathrm{~kg} \mathrm{ha}^{-1}$ as Potassium sulphateplus 0.5 per cent $\mathrm{K}_{2} \mathrm{SO}_{4}$ as foliar spray plus 100 per cent $\mathrm{RDF}\left(\mathrm{T}_{9}\right)$ of 7.4 followed by S@20 $\mathrm{kg} \mathrm{ha}^{-1}$ as Potassium sulphate plus 100 per cent RDF $\left(\mathrm{T}_{8}\right)$ of 7.1 in Vylogam series. In the case of Peelamedu series, $\mathrm{T}_{9}$ recorded the highest number of seeds per pod (8.4) closely followed by $\mathrm{T}_{8}$ (8.1) as compared to other treatments in blackgram. This might due to synergism between $\mathrm{S}$ and most of nutrients which was responsible for higher growth, yield and also leads to encourage the nutrient availability and assimilation. This result was in concurrence with the findings of Vaiyapuri et al., (2010) who revealed that application of $\mathrm{S}$ @ $30 \mathrm{~kg} \mathrm{ha}^{-1}$ increases all yield attributing characters viz., no. of branches plant ${ }^{-1}$, no. of pods plant ${ }^{-1}$, no. of seeds $\operatorname{pod}^{-1}$ and 100 seed weight of soybean due to better plant metabolism.

Table.1 Initial physico - chemical properties of the experimental site I \& II

\begin{tabular}{|c|c|c|c|}
\hline S. No. & Soil Parameters & Vylogam & Peelamedu \\
\hline A. & Particle size distribution & & \\
\hline 1. & Textural class & Sandy clay loam & Clay loam \\
\hline B. & Physical properties & & \\
\hline 1. & Bulk density $\left(\mathrm{Mg} \mathrm{m}^{-3}\right)$ & 1.37 & 1.30 \\
\hline 2. & Particle density $\left(\mathrm{Mg} \mathrm{m}^{-3}\right)$ & 2.71 & 1.96 \\
\hline 3. & Water holding capacity (\%) & 31.9 & 41.4 \\
\hline 4. & Pore space $(\%)$ & 36.4 & 47.6 \\
\hline C. & Physico- chemical properties & & \\
\hline 1. & Soil reaction $(\mathrm{pH})$ & 7.17 & 7.89 \\
\hline 2. & $\mathrm{EC}\left(\mathrm{dSm}^{-1}\right)$ & 0.43 & 0.3 \\
\hline 3. & $\operatorname{CEC}\left(\mathrm{c} \mathrm{mol}\left(\mathrm{p}^{+}\right) \mathrm{kg}^{-1}\right)$ & 12.3 & 19.8 \\
\hline 4. & $\operatorname{AEC}\left(\mathrm{c} \mathrm{mol}_{\mathrm{c}} \mathrm{kg}^{-1}\right)$ & 4.20 & 2.40 \\
\hline D. & Chemical properties & & \\
\hline 1. & Total Sesquioxides (\%) & 12.6 & 4.50 \\
\hline 2. & Organic carbon $\left(\mathrm{g} \mathrm{kg}^{-1}\right)$ & 5.43 & 4.10 \\
\hline 3. & Total nitrogen (\%) & 0.052 & 0.043 \\
\hline 4. & Total phosphorus (\%) & 0.047 & 0.051 \\
\hline 5. & Total potassium $(\%)$ & 0.283 & 0.55 \\
\hline 6. & Alk- $\mathrm{KMnO}_{4}-\mathrm{N}\left(\mathrm{kg} \mathrm{ha}^{-1}\right)$ & 234 & 261 \\
\hline 7. & Olsen - $\mathrm{P}\left(\mathrm{kg} \mathrm{ha}^{-1}\right)$ & 24.8 & 25.4 \\
\hline 8. & $\mathrm{NH}_{4} \mathrm{Oac}-\mathrm{K}\left(\mathrm{kg} \mathrm{ha}^{-1}\right)$ & 244 & 298 \\
\hline 9. & $\mathrm{CaCl}_{2}-\mathrm{S}\left(\mathrm{mg} \mathrm{kg}^{-1}\right)$ & 9.9 & 9.30 \\
\hline 10. & Exchangeable $\mathrm{Ca}\left(\mathrm{c} \mathrm{mol}(\mathrm{p}+) \mathrm{kg}^{-1}\right)$ & 7.80 & 11.6 \\
\hline 11. & Exchangeable $\mathrm{Mg}\left(\mathrm{c} \mathrm{mol}(\mathrm{p}+) \mathrm{kg}^{-1}\right)$ & 2.92 & 5.89 \\
\hline 12. & DTPA extractable $\mathrm{Zn}\left(\mathrm{mg} \mathrm{kg}^{-1}\right)$ & 0.92 & 1.78 \\
\hline 13. & DTPA extractable $\mathrm{Fe}\left(\mathrm{mg} \mathrm{kg}^{-1}\right)$ & 9.10 & 4.10 \\
\hline 14. & DTPA extractable $\mathrm{Cu}\left(\mathrm{mg} \mathrm{kg}^{-1}\right)$ & 1.64 & 3.14 \\
\hline 15. & DTPA extractable $\mathrm{Mn}\left(\mathrm{mg} \mathrm{kg}^{-1}\right)$ & 34.8 & 16.5 \\
\hline
\end{tabular}


Table.2 Effect of sulphur on growth and yield attributes of blackgram (VBN 4) in Vylogam (Typic Rhodustalf) and Peelamedu (Typic Haplustert) series

\begin{tabular}{|c|c|c|c|c|c|c|c|c|c|c|}
\hline \multicolumn{6}{|c|}{ Vylogam (Typic Rhodustalf) } & \multicolumn{5}{|c|}{ Peelamedu (Typic Haplustert) } \\
\hline Treatment & $\begin{array}{c}\text { Plant } \\
\text { height } \\
(\mathbf{c m})\end{array}$ & $\begin{array}{l}\text { No. leaves } \\
\text { plant }^{-1}\end{array}$ & $\begin{array}{c}\text { No of } \\
\text { pods plant } \\
-1\end{array}$ & $\begin{array}{l}\text { No of } \\
\text { seeds } \\
\text { pod }^{-1} \\
\end{array}$ & $\begin{array}{l}100 \text { grain } \\
\text { weight }(g)\end{array}$ & $\begin{array}{c}\text { Plant } \\
\text { height } \\
(\mathrm{cm})\end{array}$ & $\begin{array}{c}\text { No. } \\
\text { leaves } \\
\text { plant }^{-1}\end{array}$ & $\begin{array}{c}\text { No of } \\
\text { pods }^{-1} \\
\text { plant }^{-1}\end{array}$ & $\begin{array}{l}\text { No of } \\
\text { seeds } \\
\text { pod }^{-1}\end{array}$ & $\begin{array}{l}100 \text { grain } \\
\text { weight }(g)\end{array}$ \\
\hline $\mathrm{T}_{1}$ & 45.4 & 37.1 & 24.7 & 5.1 & 4.75 & 44.8 & 38.2 & 28.9 & 6.1 & 4.76 \\
\hline $\mathrm{T}_{2}$ & 45.9 & 43.4 & 27.2 & 5.2 & 4.76 & 47.4 & 42.8 & 31.3 & 6.3 & 4.77 \\
\hline $\mathrm{T}_{3}$ & 46.3 & 45.3 & 28.1 & 5.4 & 4.76 & 47.9 & 45.9 & 31.9 & 6.5 & 4.77 \\
\hline $\mathrm{T}_{4}$ & 46.4 & 46.2 & 28.4 & 6.3 & 4.77 & 48.5 & 47.8 & 32.8 & 7.2 & 4.78 \\
\hline $\mathrm{T}_{5}$ & 47.2 & 46.4 & 29.1 & 6.5 & 4.78 & 49.0 & 48.3 & 34.2 & 7.4 & 4.79 \\
\hline $\mathrm{T}_{6}$ & 52.3 & 49.3 & 30.9 & 5.5 & 4.79 & 53.8 & 52.7 & 35.3 & 6.4 & 4.80 \\
\hline $\mathrm{T}_{7}$ & 53.2 & 50.9 & 32.8 & 6.4 & 4.80 & 54.2 & 50.2 & 36.9 & 7.3 & 4.81 \\
\hline $\mathrm{T}_{8}$ & 54.5 & 52.8 & 33.2 & 7.1 & 4.80 & 55.3 & 53.1 & 37.4 & 8.1 & 4.81 \\
\hline $\mathrm{T}_{9}$ & 54.7 & 54.8 & 34.7 & 7.4 & 4.81 & 55.9 & 58.8 & 38.8 & 8.4 & 4.82 \\
\hline $\mathrm{T}_{10}$ & 47.3 & 47.2 & 27.4 & 5.3 & 4.78 & 49.3 & 48.4 & 31.4 & 6.2 & 4.79 \\
\hline $\mathrm{T}_{11}$ & 47.5 & 47.9 & 30.2 & 5.5 & 4.79 & 49.7 & 49.2 & 33.2 & 6.5 & 4.80 \\
\hline $\mathrm{T}_{12}$ & 47.7 & 48.9 & 30.9 & 6.2 & 4.79 & 50.1 & 51.1 & 35.1 & 7.3 & 4.80 \\
\hline $\mathrm{T}_{13}$ & 51.7 & 49.2 & 32.1 & 6.5 & 4.80 & 52.9 & 52.9 & 35.9 & 7.2 & 4.81 \\
\hline $\mathrm{T}_{14}$ & 45.3 & 39.9 & 26.3 & 5.1 & 4.76 & 45.7 & 41.4 & 30.1 & 6.4 & 4.77 \\
\hline Mean & 48.9 & 47.1 & 29.7 & 6.0 & 4.78 & 50.3 & 48.6 & 33.8 & 7.0 & 4.79 \\
\hline SEd & 1.02 & 0.95 & 1.51 & 0.1 & 0.10 & 1.02 & 1.11 & 0.68 & 0.2 & 0.10 \\
\hline $\mathrm{CD}(\mathrm{p}=0.05)$ & 2.09 & 1.96 & 3.02 & 0.3 & $0.20(\mathrm{NS})$ & 2.10 & 2.28 & 1.40 & 0.4 & $0.21(\mathrm{NS})$ \\
\hline
\end{tabular}


Table.3 Effect of sulphur application on grain and haulm yield $\left(\mathrm{kg} \mathrm{ha}^{-1}\right)$ of blackgram in Vylogam (TypicRhodustalf) and Peelamedu (Typic Haplustert) series

\begin{tabular}{|c|c|c|c|c|}
\hline \multirow[b]{2}{*}{ Treatment } & \multicolumn{2}{|c|}{ Vylogam (TypicRhodustalf) } & \multicolumn{2}{|c|}{ Peelamedu (TypicHaplustert) } \\
\hline & $\begin{array}{l}\text { Grain Yield } \\
\quad\left(\mathrm{kg} \mathrm{ha}^{-1}\right)\end{array}$ & $\begin{array}{l}\text { Haulm Yield } \\
\quad\left(\mathrm{kg} \mathrm{ha}^{-1}\right)\end{array}$ & $\begin{array}{l}\text { Grain Yield } \\
\quad\left(\mathrm{kg} \mathrm{ha}^{-1}\right)\end{array}$ & $\begin{array}{l}\text { Haulm Yield } \\
\quad\left(\mathrm{kg} \mathrm{ha}^{-1}\right)\end{array}$ \\
\hline $100 \%$ recommended dose of fertilisers(RDF) & 807 & 982 & 825 & 1098 \\
\hline $\mathrm{T}_{1}+\mathrm{S}\left(10 \mathrm{~kg} \mathrm{ha}^{-1}\right)$ as Gypsum & 858 & 1089 & 983 & 1187 \\
\hline $\mathrm{T}_{2}+$ Foliar spray $0.5 \% \mathrm{~K}_{2} \mathrm{SO}_{4}$ at $30^{\text {th }}$ and $45^{\text {th }} \mathrm{DAS}$ & 879 & 1107 & 1008 & 1221 \\
\hline $\mathrm{T}_{1}+\mathrm{S}\left(20 \mathrm{~kg} \mathrm{ha}^{-1}\right)$ as Gypsum & 899 & 1132 & 1025 & 1290 \\
\hline $\mathrm{T}_{4}+$ Foliar spray $0.5 \% \mathrm{~K}_{2} \mathrm{SO}_{4}$ at $30^{\text {th }}$ and $45^{\text {th }} \mathrm{DAS}$ & 921 & 1221 & 1033 & 1356 \\
\hline $\mathrm{T}_{1}+\mathrm{S}\left(10 \mathrm{~kg} \mathrm{ha}^{-1}\right)$ as Potassium sulphate & 1049 & 1332 & 1142 & 1435 \\
\hline $\mathrm{T}_{6}+$ Foliar spray $0.5 \% \mathrm{~K}_{2} \mathrm{SO}_{4}$ at $30^{\text {th }}$ and $45^{\text {th }} \mathrm{DAS}$ & 1098 & 1411 & 1167 & 1553 \\
\hline $\mathrm{T}_{1}+\mathrm{S}\left(20 \mathrm{~kg} \mathrm{ha}^{-1}\right)$ as Potassium sulphate & 1101 & 1598 & 1217 & 1878 \\
\hline $\mathrm{T}_{8}+$ Foliar spray $0.5 \% \mathrm{~K}_{2} \mathrm{SO}_{4}$ at $30^{\text {th }}$ and $45^{\text {th }} \mathrm{DAS}$ & 1145 & 1645 & 1275 & 1990 \\
\hline $\mathrm{T}_{1}+\mathrm{S}\left(10 \mathrm{~kg} \mathrm{ha}^{-1}\right)$ as Ammonium sulphate & 945 & 1288 & 1075 & 1389 \\
\hline $\mathrm{T}_{10}+$ Foliar spray $0.5 \% \mathrm{~K}_{2} \mathrm{SO}_{4}$ at $30^{\text {th }}$ and $45^{\text {th }} \mathrm{DAS}$ & 953 & 1394 & 1100 & 1493 \\
\hline $\mathrm{T}_{1}+\mathrm{S}\left(20 \mathrm{~kg} \mathrm{ha}^{-1}\right)$ as Ammonium sulphate & 986 & 1476 & 1200 & 1623 \\
\hline $\mathrm{T}_{12}+$ Foliar spray $0.5 \% \mathrm{~K}_{2} \mathrm{SO}_{4}$ at $30^{\text {th }}$ and $45^{\text {th }} \mathrm{DAS}$ & 999 & 1520 & 1208 & 1765 \\
\hline $\mathrm{T}_{1}+$ Foliar spray $0.5 \% \mathrm{~K}_{2} \mathrm{SO}_{4}$ at $30^{\text {th }}$ and $45^{\text {th }}$ DAS & 825 & 1012 & 907 & 1136 \\
\hline Mean & 962 & 1301 & 1083 & 1458 \\
\hline SEd & 23 & 36 & 26.4 & 29.7 \\
\hline $\mathrm{CD}(\mathrm{p}=0.05)$ & 48 & 74 & 54.3 & 61.1 \\
\hline
\end{tabular}


Table.4 Effect of sulphur application on quality parameters of black gram (VBN 4) in Vylogam (Typic Rhodustalf) and Peelamedu (Typic Haplustert) series

\begin{tabular}{|c|c|c|c|c|}
\hline \multirow[b]{2}{*}{ Treatments } & \multicolumn{2}{|c|}{ Vylogam (TypicRhodustalf) } & \multicolumn{2}{|c|}{ Peelamedu (TypicHaplustert) } \\
\hline & Protein $(\%)$ & $\begin{array}{c}\text { Methionine (mg } \\
\left.\mathbf{g}^{-1}\right)\end{array}$ & Protein $(\%)$ & $\begin{array}{l}\text { Methionine } \\
\left(\mathrm{mg} \mathrm{g}^{-1}\right)\end{array}$ \\
\hline $100 \%$ recommended dose of fertilisers(RDF) & 18.1 & 6.76 & 18.9 & 6.79 \\
\hline $\mathrm{T}_{1}+\mathrm{S}\left(10 \mathrm{~kg} \mathrm{ha}^{-1}\right)$ as Gypsum & 18.9 & 7.12 & 19.8 & 7.17 \\
\hline $\mathrm{T}_{2}+$ Foliar spray $0.5 \% \mathrm{~K}_{2} \mathrm{SO}_{4}$ at $30^{\text {th }}$ and $45^{\text {th }} \mathrm{DAS}$ & 19.3 & 7.52 & 20.4 & 7.58 \\
\hline $\mathrm{T}_{1}+\mathrm{S}\left(20 \mathrm{~kg} \mathrm{ha}^{-1}\right)$ as Gypsum & 19.9 & 7.60 & 21.3 & 7.67 \\
\hline $\mathrm{T}_{4}+$ Foliar spray $0.5 \% \mathrm{~K}_{2} \mathrm{SO}_{4}$ at $30^{\text {th }}$ and $45^{\text {th }} \mathrm{DAS}$ & 21.1 & 7.76 & 22.2 & 7.82 \\
\hline $\mathrm{T}_{1}+\mathrm{S}\left(10 \mathrm{~kg} \mathrm{ha}^{-1}\right)$ as Potassium sulphate & 21.9 & 8.36 & 22.8 & 8.39 \\
\hline $\mathrm{T}_{6}+$ Foliar spray $0.5 \% \mathrm{~K}_{2} \mathrm{SO}_{4}$ at $30^{\text {th }}$ and $45^{\text {th }} \mathrm{DAS}$ & 22.2 & 8.40 & 23.4 & 8.45 \\
\hline $\mathrm{T}_{1}+\mathrm{S}\left(20 \mathrm{~kg} \mathrm{ha}^{-1}\right)$ as Potassium sulphate & 22.5 & 8.76 & 23.7 & 8.78 \\
\hline $\mathrm{T}_{8}+$ Foliar spray $0.5 \% \mathrm{~K}_{2} \mathrm{SO}_{4}$ at $30^{\text {th }}$ and $45^{\text {th }} \mathrm{DAS}$ & 23.0 & 8.92 & 24.2 & 8.97 \\
\hline $\mathrm{T}_{1}+\mathrm{S}\left(10 \mathrm{~kg} \mathrm{ha}^{-1}\right)$ as Ammonium sulphate & 20.2 & 7.96 & 21.5 & 8.02 \\
\hline $\mathrm{T}_{10}+$ Foliar spray $0.5 \% \mathrm{~K}_{2} \mathrm{SO}_{4}$ at $30^{\text {th }}$ and $45^{\text {th }}$ DAS & 20.5 & 8.00 & 21.7 & 8.08 \\
\hline $\mathrm{T}_{1}+\mathrm{S}\left(20 \mathrm{~kg} \mathrm{ha}^{-1}\right)$ as Ammonium sulphate & 20.7 & 8.32 & 22.0 & 8.37 \\
\hline $\mathrm{T}_{12}+$ Foliar spray $0.5 \% \mathrm{~K}_{2} \mathrm{SO}_{4}$ at $30^{\text {th }}$ and $45^{\text {th }} \mathrm{DAS}$ & 21.0 & 8.60 & 22.3 & 8.68 \\
\hline $\mathrm{T}_{1}+$ Foliar spray $0.5 \% \mathrm{~K}_{2} \mathrm{SO}_{4}$ at $30^{\text {th }}$ and $45^{\text {th }}$ DAS & 18.6 & 6.88 & 19.2 & 6.94 \\
\hline Mean & 20.6 & 7.93 & 21.7 & 7.98 \\
\hline SEd & 0.46 & 0.14 & 0.39 & 0.16 \\
\hline$C D(p=0.05)$ & 0.94 & 0.30 & 0.79 & 0.34 \\
\hline
\end{tabular}


Effect of sulphur on grain and haulm yield of blackgram

The grain and haulm yield of blackgram was significantly influenced by the application of $\mathrm{S}$ (Table 3).The grain and haulm yield ranged from 807 to 1145,982 to 1645,825 to 1275 and 1098 to $1990 \mathrm{~kg} \mathrm{ha}^{-1}$ in Vylogam series and Peelamedu series respectively. Among the treatments, $\mathrm{T}_{9}$ registered significantly highest grain yield of 1145 and $1275 \mathrm{~kg} \mathrm{ha}^{-1}$ and haulm yield of 1645 and $1990 \mathrm{~kg} \mathrm{ha}^{-1}$ in Vylogam series and Peelamedu series and this was on par with $\mathrm{T}_{8}\left(\mathrm{~S} @ 20 \mathrm{~kg} \mathrm{ha}^{-1}\right.$ as Potassium sulphate plus $100 \% \mathrm{RDF}$ ) the grain and haulm yield of 1101 and $1598 \mathrm{~kg}$ $\mathrm{ha}^{-1}, 1217$ and $1878 \mathrm{~kg} \mathrm{ha}^{-1}$ in Vylgam and Peelamedu series respectively. The lowest grain and haulm yields were noted in control of 807 and $982 \mathrm{~kg} \mathrm{ha}^{-1}, 825$ and $1098 \mathrm{~kg} \mathrm{ha}^{-1}$ in Vylogam series andPeelamedu series respectively. It is an established fact that photosynthesis together with availability of assimilates (source) and storage (sink) exert an important regulative function on the complex process of yield formation. Application of sulphur could have improved the nitrate recovery and diversion of greater proportion of assimilation to developing pods. This result was in close association with the findings of Shubhangi et al., (2014) and Kokani et al., (2014) who reported that the grain (1153 kg ha $\left.{ }^{-1}\right)$ and haulm (2548 kg ha $\left.{ }^{-1}\right)$ yields of blackgram produced significantly higher with S@ $20 \mathrm{~kg} \mathrm{ha}^{-1}$ over control.

\section{Effect of sulphur application on quality parameters of blackgram}

\section{Protein content}

The protein content of blackgram varied from 18.1 to 23.0 and 18.9 to 24.2 per cent in Vylogam and Peelamedu series respectively (Table 4). Among the treatments, application of S@20 kg ha ${ }^{-1}$ as Potassium sulphate plus
0.5 per cent $\mathrm{K}_{2} \mathrm{SO}_{4}$ foliar spray plus 100 per cent RDF $\left(\mathrm{T}_{9}\right)$ recorded the highest protein content of 23.0 per cent in which was on par with application of $\mathrm{S} @ 20 \mathrm{~kg} \mathrm{ha}^{-1}$ as Potassium sulphate plus 100 per cent RDF $\left(\mathrm{T}_{8}\right)(22.5 \%)$ in Vylogam series. In Peelamedu series, the same treatment $\mathrm{T}_{9}$ recorded the highest protein content of 24.2 per cent followed by $\mathrm{T}_{8}(23.7 \%)$ in blackgram. Application of S serves for several structural, regulation of secondary metabolites and catalytic functions in the sense of proteins, tripeptide glutathione (redox buffer) and certain proteins such as thioredoxin, glutaredoxin and protein disulphide isomerase. This attributing to regulation activity, involved in light reaction $\left(\mathrm{CO}_{2}\right.$ fixation) of photosynthesis, which will increase the assimilation of $\mathrm{N}$ and $\mathrm{S}$ responsible for $\mathrm{S}$ containing amino acids, viz., methionine and cysteine.

In both the sites, the soil organic matter was found to be low to medium in status which would have showed less competition to sorption sites, which leads to $\mathrm{SO}_{4}{ }^{2-}$ concentration higher in solution phase. High tenacity of $\mathrm{SO}_{4}{ }^{2-}$ induced higher $\mathrm{NO}_{3}{ }^{-}$and $\mathrm{SO}_{4}{ }^{2-}$ absorption and translocation in tissues. Sulphur and nitrogen both are required for the synthesis of protein and indeed the ratio of total $\mathrm{N}$ to total $\mathrm{S}$ in plant tissue can reflect the ability of $\mathrm{N}$ and $\mathrm{S}$ in protein synthesis. Thus, a change in the ratio of reduced-N to reduced-S (NR/SR), which is a reflection of the amount of $\mathrm{S}$ in amino acids, suggests that protein metabolism has been significantly altered which has important implications in maintain protein quality. This result was corroborating with the findings of Singh and Sarkar (2013) who revealed that sulphur applied to these low S soils not only increase the crop yields, but also affect crop quality such as oil content of oilseeds and protein content of pulses. As S is an important constituent of some essential amino acids (e.g., cysteine, cystine and 
methionine), soil $\mathrm{S}$ deficiency can lower protein quality.

\section{Methionine content}

As in the case of protein, the methionine content of blackgram was also significantly influenced by $\mathrm{S}$ application and it varied from 6.76 to 8.92 and 6.79 to $8.97 \mathrm{mg} \mathrm{g}^{-1}$ in Vylogam and Peelamedu series. While comparing the treatments, application of S @ $20 \mathrm{~kg} \mathrm{ha}^{-1}$ asPotassium sulphateplus 0.5 per cent $\mathrm{K}_{2} \mathrm{SO}_{4}$ asfoliar spray plus 100 per cent RDF $\left(\mathrm{T}_{9}\right)$ recorded significantly the highest methionine content of $8.92 \mathrm{mg} \mathrm{g}^{-1}$ in Vylogam series and this was on par with application of $S$ @ $20 \mathrm{~kg} \mathrm{ha}^{-1}$ as Potassium sulphate plus 100 per cent RDF $\left(\mathrm{T}_{8}\right)(8.76 \mathrm{mg}$ $\left.\mathrm{g}^{-1}\right)$. In Peelamedu series the highest methionine content was recorded in $\mathrm{T}_{9}(8.97$ $\left.\mathrm{mg} \mathrm{g}^{-1}\right)$ followed by $\mathrm{T}_{8}\left(8.78 \mathrm{mg} \mathrm{g}^{-1}\right)$. The lowest methionine content was registered in control $\left(6.79 \mathrm{mg} \mathrm{g}^{-1}\right)$. This was ascribed by application of $\mathrm{S}$ regulating nitrate reductase enzyme (Nitrate assimilation pathway), these leads to maintain the $\mathrm{N}$ : $\mathrm{S}(15: 1)$ ratio in blackgram plant tissues. Nitrogen is found to be responsible for regulation of $\mathrm{SO}_{4}{ }^{2-}$ assimilation in ATP-sulphurylase.

In both the locations $\mathrm{SO}_{4}{ }^{2-}$ adsorption were higher leads to higher $\mathrm{NO}_{3}{ }^{-}$retention in solution phase of soil. Application of sulphur increases sulphur availability which has a role in regulating nitrate reductase, in addition to its role in regulating ATP-sulphurylase. Moreover, nitrogen availability has a role in regulating ATP-sulphurylase as well as in regulating nitrate reductase. The synthesis of cysteine as a result of the incorporation of sulphide moiety into $\mathrm{O}$ acetylserine appears to be the meeting point between $\mathrm{N}$-and $\mathrm{S}$ metabolism. This result was corroborating with the findings of Josefsson (1970) who found that $\mathrm{S}$ fertilization had increased the $\mathrm{S}$ containing amino acids in rapeseed and
Jarvan et al., (2008) reported an increase in cysteine and methionine content in wheat grain due to $\mathrm{S}$ fertilization.

It could be concluded that, in Tamil Nadu most of the soils are red soils with higher free iron and aluminum oxides, low CEC and low to medium organic carbon status which was less fertile compared to black soils. Application of sulphur in Vylogam series increases the adsorption of $S$ leads to increase the macro and micro nutrient availability in soil. Sulphur showed synergism with macro nutrients $(\mathrm{N}, \mathrm{P}, \mathrm{K}$ and $\mathrm{S})$ and micro nutrients $(\mathrm{Zn}, \mathrm{Fe}, \mathrm{Mn}$ and $\mathrm{Cu}$ ) in soil. The availability criteria have increased the assimilation of nutrients from source to sink which encourages the content, uptake and yield of blackgram. In Peelamedu series, sesquioxides content was low when compared to Vylogam series but this series had high amount of $\mathrm{Ca}$ and $\mathrm{Mg}$ leads the chemisorption of some anions leads to deficiency of phosphorus, sulphur and micro nutrients due to higher $\mathrm{pH}$. Application of sulphur in this series has improved the overall soil rhizosphere environment which leads to improve the nutrient status of this series. In both the locations Potassium sulphate $\left(20 \mathrm{~kg} \mathrm{ha}^{-1}\right.$ and $0.5 \%$ foliar spray) is found as a best source as compared to ammonium sulphate and gypsum. Hence in order to improve the productivity of blackgram in pulses growing soils of Madurai district in addition to recommended dose of $\mathrm{N}, \mathrm{P}_{2} \mathrm{O}_{5}$ and $\mathrm{K}_{2} \mathrm{O}$, soil application of $20 \mathrm{~kg} \mathrm{ha}^{-1}$ as Potassium sulphate plus foliar spray of 0.5 per cent $\mathrm{K}_{2} \mathrm{SO}_{4}$ on 30 DAS and 45 DAS is essential to reduce the sub optimal yield.

\section{Acknowledgements}

The authors are grateful to University Grand Commission for aided Rajiv Gandhi National Fellowship for financial support during this study. 


\section{References}

Brunold, C., and Suter, M.1984. Regulation of sulfate assimilation by nitrogen nutrition in the duckweed Lemna minor L. Plant Physiology. 76, 579-583.

Chaturvedi, S.K., and Masood Ali.2002. Poor man's meat needs fresh fillip. Survey of Indian Agric. pp. 63- 70.

Fahmina Akter, M.D. Nurul Islam, A.T.M. Shamsuddoha, M.S.I. Bhuiyan, and Sonia Shilpi. 2013. Effect of Phosphorus and Sulphur on Growth and Yield of Soybean (Glycine max L.). Int. J. Bio-resource and Stress Mgt. 4(4),555-560.

Jarvan, M., L. Edesi, A. Adamson, L. Lukme and Akk. A. 2008. The effect of sulphur fertilization on yield quality of protein and baking quality of winter wheat. Agronomy Res. 6(2), 459-469.

Josefsson, E.1970. Glucosinolate content and amino acid composition of rapeseed (Brassica napus L.) meal as affected by sulfur and nitrogen nutrition. J Sci Food Agric. 21: 98-103.

Kokani, J.M., K.A. Shah, B.M. Tandel and Nayaka, P.2014. Growth, yield attributes and yield of summer blackgram (Vigna mungo L.) as influenced by FYM, phosphorus and sulphur. The Bioscan. 6: 429-433.

McGrath S.P., F.J. Zhao and Withers, P.J.A.1996. Development of sulphur deficiency in crops and its treatments. Proceedings of the fertiliser society, No.379. Peterborough, The Fertiliser society.
Mir, A.H., S.B. Lal, M. Salmani, M. Abid and Khan, I. 2013. Growth, yield and nutrient content of blackgram (Vigna mungo) as influenced by levels of phosphorus, sulphur and phosphorus solubilizing bacteria. SAARC J. Agri. 11(1): 1-6.

Schnug, E., 1991. Sulphur nutritional status of European Crops and consequences for agriculture. Sulphur Agric. 15, 7- 12.

Sharma, M.P., and Singh, R. 1997. Effect of phosphorus and sulphur application on yield and quality of greengram (Phaseolus radiates L.). Indian Journal of Agricultural Sciences. 63(3): 507-508.

Shubhangi, J. D., V.D. Patil and Mamta, J.P. 2014. Effect of various levels of phosphorus and sulphur on yield, plant nutrient content, uptake and availability of nutrients at harvest stages of soybean [Glycine $\max$ (L.)]. Int. J. Curr. Microbiol. App. Sci. 3(12), 833-844

Singh, S., and Sarkar, A.K. 2013. Sulfur Management for Optimizing Oilseed and Pulse Production in Rain-fed Jharkhand. Better Crops. 97(2), 13-17.

Singh, V., R. Singh and Singh. 1999. Relative efficiency of sources of sulphur on lentil and its nutrition in an alluvial soil. Ann. Pl. Soil Res.1,14-17.

Vaiyapuri, K., M. Mohamed Amanullah and Rajendran, K. 2010. Influence of sulphur and boron on yield attributes and yield of soybean. Madras Agric. J.97 (1-3), 65-67.

Zhao, F.J., M.J. Hawkesford and McGrath, S.P. 1999. Sulphur assimilation and effects on yield and quality of wheat. J. Cereal. Sci. 30, 1-17.

\section{How to cite this article:}

Gokila, B., K. Baskar and Saravanapandian, P. 2017. Nutritional Significance of Sulphur on Growth, Yield and Quality of Blackgram in Major Contrasting Soil Series of Tamil Nadu, India. Int.J.Curr.Microbiol.App.Sci. 6(11): 3139-3149. doi: https://doi.org/10.20546/ijcmas.2017.611.368 